\title{
Review Indeks Glikemik Beras: Faktor-Faktor yang Mempengaruhi dan Keterkaitannya terhadap Kesehatan Tubuh
}

\section{Rice Glycemic Index: The Factors Affecting and The Impact on Human Health}

\author{
Elis Septianingrum, Liyanan, Bram Kusbiantoro \\ Balai Besar Penelitian Tanaman Padi
}

J1. Raya 9, Tromol Pos 11, Cikampek Subang 41256 - Jawa Barat Telp: 0260 - 520157. Fax: 0260 - 520158, Email: elis.septianingrum @ gmail.com

\begin{abstract}
Abstrak. Penderita penyakit Diabetes Melitus seringkali mambatasi konsumsi nasi karena beras dianggap sebagai pangan hiperglikemik, padahal dari beberapa penelitian diketahui bahwa beras mempunyai kisaran indeks glikemik yang cukup luas. Oleh karena itu, pengetahuan mengenai efek asupan karbohidrat terhadap kadar gula darah dan respon insulin berguna dalam penyusunan menu diet bagi penderita diabetes. Sebagai makanan sumber karbohidrat, konsumsi beras yang memiliki indeks glikemik (IG) rendah akan membantu mengendalikan kadar glukosa darah. Tujuan dari penulisan review ini adalah untuk memberikan informasi mengenai faktorfaktor yang mempengaruhi IG beras serta keterkaitannya terhadap kesehatan tubuh. Faktor-faktor yang mempengaruhi IG beras dianataranya adalah jenis/ varietas beras, proses pengolahan, dan perbandingan amilosa dan amilopektin. Kandungan amilosa yang tinggi terbukti memiliki kecenderungan memberikan nilai respon glikemik (IG) yang rendah. Proses pengolahan berupa pemanasan dan pratanak serta penambahan senyawa bioaktif (polifenol) diketahui mampu menurunkan IG beras. Dari segi varietas, beberapa varietas unggul padi yang mempunyai indeks glikemik rendah hingga sedang telah berhasil dirakit Balai Besar Penelitian Tanaman Padi Sukamandi. Beras-beras tersebut mempunyai karakteristik tekstur nasi yang pulen hingga pera sesuai dengan preferensi konsumen. Oleh karena itu, penderita diabetes tidak perlu khawatir mengonsumsi nasi, sepanjang tidak melebihi kebutuhan energi tiap individu.
\end{abstract}

Kata kunci: Beras, Indeks Glikemik, Pratanak, Amilosa, amilopektin, Diabetes Melitus.

\begin{abstract}
Patients with Diabetes Mellitus often restrict the consumption of rice because rice has been blamed as hyperglycemic food, whereas from several studies, it is known that rice has a board range of glycemic index. Therefore, knowledge about the effects of carbohydrate intake on blood sugar levels and insulin response is useful in the preparation of the diet for diabetics. Consumption of rice as a source of carbohydrate which has a low glycemic index (GI) will help control blood glucose levels. Low GI food will produce slow blood glucose response when is consumed. The purpose of this review was to provide basic information about factors that affect rice GI and their corellation in health. Factors that affect rice GI are species/varieties of rice, processing, and ratio of amylose and amylopectin. High amylose content has been proved to have a tendency to give low glycemic response (GI). In addition, the processing such as heating, parboiled and an addition
\end{abstract}


of bioactive compounds were known could lower GI. Some high-yielding rice varieties that have been assembled by Indonesian Center for Rice Research have a low to moderate glycemic index. They have soft and hard texture characteristic according to consumer preferences based on certain ethnic. Therefore, people with diabetes do not have to worry about eating rice, as far as they do not exceed the energy needs of each individual.

Keywords: rice, glycemic index, parboiled, amylose, amylopectin, diabetes mellitus.

\section{PENDAHULUAN}

Beras (Oryza sativa) dikonsumsi oleh 2/3 dari populasi penduduk dunia dan setengahnya (termasuk banyak negara di Amerika Latin, Asia dan Pasifik) menjadikan beras sebagai sumber utama energi dalam menu makanannya (HU et al., 2004). Beras banyak disukai karena harganya yang murah, mudah dan cepat dalam penyiapannya, dan cocok untuk dipadukan dengan berbagai jenis masakan (Denardin, 2012). Karbohidrat diketahui merupakan komponen pangan penting khususnya sebagai sumber energi. Kandungan gizi beras per 100 g bahan adalah $360 \mathrm{kkal}$ energi, 6,6 g protein, 0,58 g lemak, dan 79,34 g karbohidrat (USDA, 2011). Karbohidrat dalam bentuk glukosa, tidak hanya digunakan sebagai bahan bakar otot rangka aktif, tetapi juga bahan bakar metabolisme sel-sel saraf dan sel darah merah. Berbagai jenis karbohidrat akan memberikan efek yang berbeda terhadap tubuh. Di dalam tubuh, karbohidrat akan dipecah menjadi komponen yang lebih kecil seperti disakarida maupun monosakarida yang dapat memberikan kontribusi dalam meningkatkan kadar glukosa darah. Glukosa darah yang berlebih di dalam tubuh dapat menyebabkan masalah kesehatan seperti diabetes, hiperlipidemia, kanker, obesitas, bahkan stroke (Oba et al, 2010).

Ada banyak faktor yang dapat menyebabkan IG pangan yang satu berbeda dengan yang lainnya. Perbedaan IG dan kecernaan pati yang cukup signifikan telah ditemukan baik antar sumber tanaman maupun didalam satu sumber tanaman tunggal (Denardin, et al, 2007). Bahan pangan dengan jenis yang sama apabila diolah dengan menggunakan cara yang berbeda dapat memiliki IG yang berbeda. Hal ini dapat terjadi karena pengolahan dapat menyebabkan perubahan struktur dan komposisi kimia pangan. Rimbawan dan Siagian (2004) menjelaskan bahwa faktorfaktor yang mempengaruhi IG beras antara lain jenis/varietas beras, proses pengolahan, dan perbandingan amilosa dan amilopektin.

Sebagai makanan utama sumber karbohidrat, beras berperan penting dalam memenuhi kebutuhan akan asupan energi dan gizi karena kandungan patinya yang tinggi (90\% butir putih). Pengetahuan mengenai efek asupan karbohidrat terhadap kadar glukosa darah dan respon insulin (berdasarkan IG-nya) berguna sebagai acuan dalam menentukan jumlah dan jenis pangan sumber karbohidrat yang tepat untuk meningkatkan dan memelihara asupan pangan yang sehat. Konsumsi beras sebagai makanan pokok yang memiliki IG rendah bagi penderita diabetes melitus berguna untuk mengendalikan kadar glukosa dalam darah dikarenakan lambat untuk dicerna dan diserap maka membantu untuk mempertahankan tingkat glukosa dalam darah dan untuk mengurangi respon insulin. Denardin (2007) menjelaskan bahwa pemahaman mengenai hubungan antara Indeks glikemik beras, karakteristik (kandungan amilosa) dan sifat fungsional pati beras sangat penting dalam optimalisasi aplikasi pada industri dan memberikan pilihan bagi konsumen terhadap konsumsi beras yang memberikan manfaat kesehatan. 


\section{INDEKS GLIKEMIK}

Konsep indeks glikemik mulai diperkenalkan untuk melihat gambaran tentang hubungan antara karbohidrat dalam makanan dengan kadar glukosa darah. Indeks glikemik (IG) merupakan tingkatan pangan menurut efeknya terhadap gula darah (Rimbawan dan Siagian (2004) atau metode yang digunakan untuk mengklasifikasikan karbohidrat diet berdasarkan dampaknya terhadap respon glukosa darah (2-jam setelah makan). Kadar glukosa darah normal berkisar antara 55-140 $\mathrm{mg} / \mathrm{dl}$, dan untuk penyediaan energi bagi susunan syaraf pusat diperlukan kadar glukosa darah minimal 40-60 mg/dl.

Indeks glikemik pangan merupakan sifat bahan pangan yang sangat unik, dipengaruhi oleh jenis bahan, cara pengolahan, karakteristik (komposisi dan sifat biokimiawi) bahan, ukuran partikel (HU et al, 2004). Masing-masing komponen bahan pangan akan memberikan kontribusi dan saling berpengaruh sinergis antarsifat bahan hingga menghasilkan respon glikemik tertentu (Widowati 2007).

Nilai IG dapat dihitung setelah mengetahui luas kurva sampel (pangan uji) dan glukosa (pangan acuan), yaitu dihitung berdasarkan perbandingan antara luas kurva kenaikan glukosa darah setelah mengonsumsi pangan yang diuji dengan kenaikan glukosa darah setelah mengonsumsi pangan rujukan terstandar, seperti glukosa (Marsono et al, 2002). Nilai IG pangan berkisar antara 1-100 dan di bagi dalam tiga level, yaitu rendah $(<55)$, sedang (55-70), dan tinggi (>70) (Anonim, 2009).

\section{Keterkaitan Indeks Glikemik Beras dan Kesehatan}

Diabetes melitus merupakan penyebab kematian nomor enam pada semua kelompok umur. Jumlah penderita DM meningkat dengan cepat di seluruh dunia dan penyakit ini sudah menjadi penyakit epidemi global (Sinaga dan Wirawanni, 2012). Gaya hidup dan pola konsumsi pangan masyarakat modern yang cenderung tidak sehat telah menyebabkan meningkatnya jumlah penderita penyakit diabetes mellitus (DM). Penderita penyakit DM atau kencing manis mengalami gangguan metabolisme glukosa. Penderita mengalami gangguan metabolisme distribusi glukosa sehingga tubuh tidak dapat memproduksi insulin dalam jumlah yang cukup, atau tidak mampu menggunakan insulin secara efektif sehingga gula dalam darah berlebihan (Mcgonigal, 2008).

Hasil-hasil penelitian menunjukkan bahwa kecepatan pencernaan karbohidrat di dalam saluran pencernaan, tidak sama untuk setiap jenis pangan. Pangan yang menaikkan kadar glukosa darah dengan cepat memiliki kadar IG tinggi, sebaliknya yang menaikkan kadar glukosa darah dengan lambat memiliki indeks glikemik rendah (Atkinson et al, 2008). Makanan ber-IG tinggi menyebabkan sekresi insulin dalam jumlah besar sebagai akibat dari kenaikkan kadar glukosa darah yang tinggi dan cepat. Hal tersebut akan menyebabkan peningkatan rasa lapar setelah makan dan penumpukkan lemak pada jaringan adiposa dalam tubuh.

Kadar Glukosa Darah penderita DM dapat dikendalikan dengan pola hidup sehat (pola makan yang benar, cukup aktivitas fisik, cukup istirahat dan tidak merokok). Pateda et al, 2009 menjelaskan bahwa pada pasien DM, kadar gula darah yang terkendali akan menurunkan risiko terjadinya komplikasi akut maupun komplikasi kronis (baik mikro maupun makroangiopati) serta meningkatkan kualitas hidupnya.

Sejalan dengan itu, Franz (2012) menyebutkan bahwa, pengendalian kadar glukosa darah dapat dilakukan melalui terapi farmakologi maupun nonfarmakologi. Salah satu cara nonfarmakologi yang dapat dilakukan untuk membantu mengendalikan kadar glukosa darah yaitu melalui konsumsi makanan dengan indeks glikemik rendah.

Berdasarkan hasil penelitian Pateda et al (2009), diketahui bahwa selain pemberian obat anti diabet, konsumsi makanan yang mengandung indeks glikemik rendah yaitu beras herbal ponni secara signifikan dapat menurunkan kadar fruktosamin pasien diabetes mellitus tipe-1. Fruktosamin adalah 
hasil reaksi non-enzimatik Maillard antara residu glukosa dan asam amino yang dapat mencerminkan pengendalian glikemik. Hasil penelitian Heather et al (2001), juga menunjukkan bahwa pangan dengan IG rendah dapat memperbaiki pengendalian metabolik pada penderita DM tipe 2 .

Indrasari (2008) mengungkapkan bahwa ada sebuah konsep lama dalam manajemen diet penderita diabetes yang menganjurkan agar penderita diabetes membatasi konsumsi beras, dan beralih untuk mengonsumsi umbiumbian. Hal ini karena ada anggapan bahwa beras merupakan pangan hiperglikemik, yang dapat menaikkan kadar glukosa darah dengan cepat Padahal respon glikemik beras sangat bervariasi, dipengaruhi oleh cara pengolahan, varietas, dan komposisi kimia (Foster-Powell et al, 2002; Rimbawan dan Siagian 2004). Konsumsi pangan, terutama beras sebagai pangan pokok, yang memiliki IG rendah akan membantu memperbaiki pengendalian glikemik secara bermakna (Pateda et al, 2009). World Health Organization (WHO) merekomendasikan konsumsi makanan dengan indeks glikemik rendah untuk membantu meningkatkan pengendalian glukosa darah, namun tetap memperhatikan jumlah karbohidrat yang dikonsumsi.

\section{Faktor-Faktor yang Mempengaruhi Indeks Glikemik Beras}

a. Jenis / Varietas Beras.

Beras dari beberapa varietas unggul padi yang telah berkembang dewasa ini memiliki indeks glikemik yang rendah. Karena itu, penderita diabetes tidak perlu khawatir mengonsumsi nasi, sepanjang tidak melebihi kebutuhan energi tiap individu (Anonim, 2009).

Beberapa varietas unggul padi rakitan Balai Besar Penelitian Tanaman Padi Sukamandi mempunyai indeks glikemik rendah hingga sedang. Berasberas tersebut mempunyai karakteristik tekstur nasi yang pulen hingga pera sesuai dengan preferensi konsumen berdasarkan etnis tertentu. Inpara 4, inpara 3, dan inpari 12 cocok dikonsumsi oleh penderita diabet yang berasal dari etnis Sumatera Barat, Kalimantan Selatan maupun etnis lain yang menyukai nasi bertekstur pera. Sedangkan beras Inpari 13, Inpara 7, Inpari 1, Hipa 7, dan, Hipa 6 Jete, Hipa 5 Ceva, Inpago 7, inpari 24 Gabusan, dan Inpari 6 Jete cocok dikonsumsi oleh penderita diabet yang berasal dari etnis Jawa maupun etnis lain yang menyukai nasi bertekstur pulen. Indeks glikemik dan kadar amilosa dari beberapa varietas padi di sajikan pada Tabel 1 .

Tabel 1 Nilai Indeks Glikemik Beberapa Varietas Padi Indonesia.

\begin{tabular}{lcc}
\hline \multicolumn{1}{c}{ Varietas } & $\begin{array}{c}\text { Indeks } \\
\text { Glikemik }\end{array}$ & Tekstur Nasi \\
\hline Inpari 13 & 45 & Pulen \\
Inpara 7 & 49 & Pulen \\
Hipa 7 & 49 & Pulen \\
Inpari 1 & 50.4 & Pulen \\
Inpara 4 & 50.9 & Pera \\
Inpari 12 & 53 & Pera \\
Hipa 6 Jete & 57 & Pulen \\
Hipa 5 Ceva & 57.3 & Pulen \\
Inpago 7 & 58 & Pulen \\
Inpara 5 & 59 & Sedang \\
Inpara 3 & 59.2 & Pera \\
Inpari 24 & 64 & Pulen \\
Gabusan & 66.2 & Pulen \\
Inpari 6 Jete & & \\
\hline Sumber: BB PADI & &
\end{tabular}

Sumber: BB PADI

\section{b. Proses Pengolahan.}

Beras pada umumnya diolah melalui pemanasan sebelum di-konsumsi. Proses pemanasan tersebut dapat menyebabkan pati mengalami gelatinisasi dan apabila pati yang mengalami gelatinisasi tersebut dipanaskan kemudian didinginkan kembali maka akan menyebabkan terjadinya retrogradasi. Retrogradasi meru-pakan perubahan yang terjadi pada pati tergelatinisasi pada saat pendinginan, sehingga akan terjadi 
rekristalisasi sepenuhnya yang bersifat dapat balik (reversibel) pada amilopektin dan sebagian rekristalisasi bersifat tidak dapat balik (ireversibel) pada amilosa.

Gelatinisasi dan retrogradasi yang terjadi akan mempengaruhi kecernaan pati di dalam usus halus. Pati yang telah mengalami gelatinisasi dan retrogradasi telah terbukti tidak tercerna secara sempurna di dalam usus manusia sehingga dapat dikatakan bahwa pengolahan dapat menyebabkan terbentuknya pati tahan cerna atau Resistant Starch (Marsono, 1998).

Pembentukan Resistant Starch (RS) selama pengolahan bahan berpati seperti beras dipengaruhi oleh berbagai faktor: misalnya kandungan air bahan, $\mathrm{pH}$, suhu pemanasan, jumlah pengulangan pemanasan dan pendinginan, pembekuan dan pengeringan (Marsono, 1998). Jumlah RS pada kebanyakan produk mentah umumnya sangat rendah tetapi pengolahan dan penyimpanan dapat mengakibatkan perbedaan derajat rekristalisasi pati sehingga menyebabkan kenaikan jumlah RS.

\section{c. Proses Pratanak/Parboiled Gabah}

Beras pratanak merupakan proses pemberian air dan uap panas terhadap gabah sebelum gabah tersebut dikeringkan (Haryadi, 2006). Pada awal perkembangannya, proses pratanak dimaksudkan untuk mengawetkan gabah, karena proses pratanak dapat menyebabkan gabah tidak dapat berkecambah. Tujuan selanjutnya adalah untuk menghindari kehilangan dan kerusakan beras, baik ditinjau dari nilai gizi maupun rendemen beras (Widowati, 2008).

Pada umumnya prinsip pembuatan beras pratanak dilakukan melalui tiga tahapan proses yaitu dimulai dengan proses perendaman (steeping) gabah pada suhu dan lama waktu tertentu hingga diperoleh kadar air 30\%, kemudian dilanjutkan dengan proses pengukusan (steaming), dan pengeringan (drying) hingga dicapai kadar air aman disimpan. Gabah pratanak kemudian disimpan atau langsung digiling menjadi beras pratanak. Hasil penelitian Widowati (2009), menunjukkan bahwa cara pengolahan, dalam hal ini adalah proses pratanak terbukti dapat menurunkan IG beras. Pengaruh Perlakuan Pratanak terhadap indeks glikemik beras dapat dilihat pada Tabel 2.

Secara umum proses pratanak akan mengubah sifat fungsional beras. Widowati (2009) melaporkan bahwa proses pratanak berpengaruh terhadap sifat fungsional beras. Proses ini dapat memperlambat kenaikan glukosa darah dan menekan muculnya insulin yang dibutuhkan untuk mentransfer glukosa ke dalam sel-sel tubuh dan diubah menjadi energi (menurunkan indeks glikemiknya), meningkatkan kadar serat pangan, dan menurunkan daya cerna pati in vitro sehingga waktu tinggal di usus menjadi lebih lama. Oleh karena itu, orang yang mengonsumsi nasi dari beras pratanak akan merasa kenyang lebih lama atau tidak cepat lapar. Proses pratanak dapat meningkatkan kandungan serat pangan total antara 50-80\%, sedangkan daya cerna pati in vitro menurun $35-50 \%$ dan indeks glikemik menurun 16-32\% (Widowati, 2008).

Lebih lanjut Widowati (2008), menjelaskan bahwa beras pratanak dianjurkan untuk dikonsumsi oleh penderita diabetes melitus, individu yang berusia 40 tahun ke atas, atau bagi mereka yang ingin terhindar dari kelebihan berat badan (obesitas). Indeks glikemik yang rendah dapat mengendalikan kadar glukosa darah, sedangkan serat pangan yang tinggi akan memperlambat laju pengosongan lambung. 
Tabel 2. Pengaruh Perlakuan Pratanak terhadap Indeks Glikemik Beras

\begin{tabular}{|c|c|c|c|}
\hline \multirow[b]{2}{*}{ Varietas } & \multicolumn{2}{|c|}{ Indek Glikemik } & \multirow{2}{*}{$\begin{array}{c}\text { Perubahan } \\
(\%)^{*}\end{array}$} \\
\hline & $\begin{array}{l}\text { Beras } \\
\text { Giling }\end{array}$ & $\begin{array}{c}\text { Beras } \\
\text { Pratanak }\end{array}$ & \\
\hline Sintanur & $91.03^{\mathrm{a}}$ & $76.32^{\mathrm{a}}$ & -16.16 \\
\hline Gilirang & $97.29^{b}$ & $72.95^{\mathrm{a}}$ & -25.02 \\
\hline Ciherang & $54.43^{\mathrm{b}}$ & $44.22^{\mathrm{a}}$ & -18.76 \\
\hline IR 64 & $69.96^{\mathrm{b}}$ & $51.99^{a}$ & -25.69 \\
\hline Mekongga & $79.34^{\mathrm{b}}$ & $61.91^{\mathrm{a}}$ & -21.97 \\
\hline IR 42 & $68.52^{\mathrm{b}}$ & $46.32^{\mathrm{a}}$ & -32.40 \\
\hline $\begin{array}{l}\text { Batang } \\
\text { Lembung }\end{array}$ & $63.50^{\mathrm{b}}$ & $46.32^{\mathrm{a}}$ & -27.06 \\
\hline
\end{tabular}

\section{d. Senyawa Bioaktif (Polifenol)}

Proses pembuatan beras instan fungsional dengan memanfaatkan ekstrak teh hijau dapat menurunkan daya cerna pati in vitro dan indeks glikemiknya (dari 66 menjadi 49), sehingga berpotensi sebagai diet bagi penderita diabetes mellitus (Widowati 2007). Teh hijau diketahui kaya akan senyawa bioaktif berupa polifenol. Senyawa kompleks yang terjadi antara pati dengan polifenol menyebabkan sisi atau bagian pati yang secara normal dihidrolisis oleh enzim pencernaan menjadi tidak dikenali. Semakin banyak ikatan pati dengan polifenol maka semakin banyak sisi-sisi yang tidak dapat dikenali oleh enzim pencernaan, sehingga kemampuan hidrolisis pati menurun. Akibatnya, daya cerna pati menjadi rendah. Kecernaan pati yang rendah akan menghasilkan respon insulin yang rendah juga sehingga dapat menekan kadar gula darah dalam tubuh.

\section{e. Rasio Amilosa : Amilopektin}

Pati beras terusun atas 2 macam molekul polisakarida yaitu amilosa dan amilopektin. Amilosa merupakan polimer glukosa dengan ikatan $\alpha$-(1-4) glukosidik sedangkan amilopektin merupakan polimer glukosa dengan ikatan $\alpha-(1-$ 6) glukosidik. Berdasarkan kandungan amilosa, beras dapat dibedakan menjadi beras ketan (kadar amilosa 10-20\%), beras beramilosa sedang (kadar amilosa 20-25\%), dan beras beramilosa tinggi $(>25 \%)$

(Frei et al., 2003).

Struktur amilosa dan amilopektin yang berbeda menyebabkan daya cerna dan respon glikemik yang berbeda.

Kandungan amilosa sering digunakan untuk memprediksi tingkat kecernaan pati, indeks glikemik respon glukosa darah dan respon insulin terhadap beras. Beras yang memiliki kandungan amilosa tinggi cenderung memiliki aktivitas hipoglikemik tinggi dan nilai GI rendah (Tabel 2). Hasil penelitian Denardin et al (2012), yang menggunakan 3 jenis pakan dengan kadar amilosa yang berbeda (TAH-treatment with high amylose content; TAI-treatment with intermediate amylose content; TAL-treatment with low amylose content) terhadap daya cerna yang diamati pada tikus menunjukkan bahwa pakan yang diberikan dengan kandungan amilosa tinggi (TAH) dicerna dengan lebih lambat. Hal ini ditunjukkan dengan nilai apparent starch digestibility (ASD) yang lebih rendah dibanding dengan TAI dan TAL.

Hasil yang serupa juga dikemukakan oleh Frei et al (2003), yang meneliti nilai kecernaan (nilai $C \infty$ dan k) dan nilai indeks glikemik dari 4 cultivar beras yang memiliki kandungan amilosa berbedabeda. Kandungan amilosa yang tinggi memberikan nilai kecernaan dan skor glikemik yang lebih rendah diantara yang lainnya.

Granula pati yang lebih banyak mengandung amilosa, mempunyai struktur yang lebih kristalin yang disebabkan oleh intensifnya ikatan hidrogen. Dengan demikian amilosa sulit tergelatinisasi dan sulit dicerna. Selain itu amilosa juga mudah bergabung dan mengkristal sehingga mudah mengalami retrogradasi yang bersifat sulit dicerna 
(Mayer, (1973):Widowati, (2009). Frei et al., (2003) menjelaskan bahwa pada waktu beras mengalami proses pemanasan (dimasak), akan terjadi pembentukan kompleks antara amilosa dan lipid yang sulit untuk dapat diakses oleh enzimatik pencernaan sehingga menghasilkan laju pencernaan yang lambat. Namun, disebutkan juga bahwa beras dengan kandungan amilosa yang sama dapat berbeda dalam kecernaan pati dan respon glikemik. Hal ini dapat dipahami bahwa selain dari rasio amilosa : amilopektin, sifat pati seperti ukuran butiran, tipe ikatan amilosa-amilopektin dengan komponen lain, pola kristal, tingkat kristalinitas, pori-pori permukaan, derajat polimerisasi, dan komponen nonpati mempengaruhi daya cerna pati.

Tabel 3. Kandungan Amilosa dan Indeks Glikemik (IG) Beberapa Varietas Beras

\begin{tabular}{|c|c|c|c|}
\hline Cultivar & $\begin{array}{c}\text { Kandungan } \\
\text { Amilosa } \\
(\%)\end{array}$ & IG & Sumber \\
\hline BR-14 & 27 & $\begin{array}{l}54.5 \pm \\
16.1\end{array}$ & $\begin{array}{l}\text { (Fatema,et al, } \\
2010)\end{array}$ \\
\hline BR-29 & 29.4 & $\begin{array}{l}50.3 \pm \\
19.3\end{array}$ & $\begin{array}{l}\text { (Fatema,et al, } \\
\text { 2010) }\end{array}$ \\
\hline Milagrosa & 26,9 & $68.0 \pm 3.7$ & $\begin{array}{l}\text { (Frei et al., } \\
\text { 2003) }\end{array}$ \\
\hline Manumbaeay & 29,9 & $87.3 \pm 2.7$ & $\begin{array}{l}\text { (Frei et al.,, } \\
\text { 2003) }\end{array}$ \\
\hline Kutsiyam & 18,7 & $68.5 \pm 3.2$ & $\begin{array}{l}\text { (Frei et al., } \\
\text { 2003) }\end{array}$ \\
\hline Kinaures & 9,8 & $96.9 \pm 2.5$ & $\begin{array}{l}\text { (Frei et al., } \\
2003 \text { ) }\end{array}$ \\
\hline Bagoean & 0 & $92.3 \pm 4.8$ & $\begin{array}{l}\text { (Frei et al., } \\
\text { 2003) }\end{array}$ \\
\hline Karaya & 0 & $\begin{array}{l}109.2 \pm \\
0.9\end{array}$ & $\begin{array}{l}\text { (Frei et al., } \\
2003 \text { ) }\end{array}$ \\
\hline Zhefu504 & 13.2 & $98.5 \pm 4.6$ & $\begin{array}{l}\text { (Hu, et al, } \\
2004)\end{array}$ \\
\hline Zanuo & 0.7 & $99.5 \pm 1.6$ & $\begin{array}{l}\text { (Hu, et al, } \\
2004)\end{array}$ \\
\hline
\end{tabular}

Amilosa juga merupakan parameter utama yang menentukan mutu tanak dan mutu rasa nasi. Beras dengan indeks glikemik rendah umumnya mempunyai tekstur nasi pera. Beras yang mengandung amilosa tinggi bila ditanak akan menghasilkan nasi pera dan tekstur keras setelah dingin, sebaliknya kandungan amilosa pada beras yang rendah akan menghasilkan nasi pulen dan teskturnya lunak.

\section{PENUTUP}

Pengetahuan mengenai efek asupan karbohidrat terhadap kadar gula darah dan respon insulin (berdasarkan IG-nya) berguna sebagai acuan dalam menentukan jumlah dan

jenis pangan sumber karbohidrat yang tepat untuk meningkatkan dan memelihara asupan pangan yang sehat. Kondisi ini relevan, terutama dalam penyusunan menu diet bagi penderita diabetes, dikarenakan lambat untuk dicerna dan diserap maka membantu untuk mempertahankan tingkat glukosa dalam darah dan untuk mengurangi respon insulin. Faktorfaktor yang mempengaruhi IG beras antara lain jenis/varietas beras, proses pengolahan, dan perbandingan amilosa dan amilopektin. Proses pengolahan berupa pemanasan dan parboiled serta penambahan senyawa bioaktif (polifenol) diketahui mampu menurunkan IG beras. Selain itu kandungan amilosa yang tinggi terbukti memiliki kecenderungan memberikan nilai respon glikemik (IG) yang rendah. 


\section{DAFTAR PUSTAKA}

Anonim. 2009. Beras Untuk Penderita Diabetes. Warta Penelitian dan Pengembangan Pertanian. Vol. 31. No. 2. 2009.

Atkinson, F.S., K. Foster-Powell, and J.C. Brand Miller. 2008. International tables of glycemic index and glycemic load values: 2008. Diabetes Care 31: 2281 $\square-2283$.

BB PADI. 2014. Deskripsi Varietas Padi. Balai Besar Penelitian Tanaman Padi. Badan Penelitian dan Pengembangan Pertanian. Kementerian Pertanian.

Denardin, C.C., Walter, M., dan Silva, L.P., Souto, G.D. and Fagundes, C.A.A. 2007. Effect of amylose content of rice varieties on glycemic metabolism and biological responses in rats. Food Chemistry 105: 1474-1479.

Denardin., Cristiane, C., Nardeli, B., Patrícia, R., Leila, P., Silva, M.W. 2012. Amylose content in rice (Oryza sativa) affects erformance, glycemic and lipidic metabolism in rats. rice (Oryza sativa) affects performance, glycemic and lipidic metabolism in rats 1. Ciência Rural, v.42, n.2, fev, 2012.

Fatema, Kaniz, Farzana, R., Nurunnahar, S, Khadizatul, Kobura., Liaquat, A. 2010. Glycemic index of three common varieties of Bangladeshi rice in healthy subjects. African Journal of Food Science Vol. 4(8) pp. 531 - 535, August 2010.

Franz, MJ. 2012. Medical nutrition therapy for diabetes mellitus and hypoglycemia of nondiabetic origin. In : Mahan LK, Escott-Stump S, Raymond JL. Krause's food and nutrition care process. 13th ed. Philadephia: WB Saunders; 2012.p.675-709.

Frei, M.P., Siddhuraju, K., Becker. 2003. Studies on the in vitro starch digestibility and the glycemic index of six different indigenous rice cultivars from the Philippines. Food Chemistry 83: 395-402.

Haryadi. 2006. Teknologi Pengolahan Beras. Yogyakarta. Gadjah Mada University Press.

Heather R, et al. 2001. The effect of flexible low glycemic index dietary advice versus measured carbohydrate exchange diets on glycemic control in children with type 1 diabetes. Diab Care Vol. 24:1137-1143.

HU, P. et al. 2004. Starch Digestibility And The Estimated Glycemic Score Of Different Types Of Rice Differing In Amylose Contents. Journal of Cereal Science, v.40, p.231-237, 2004.

Indrasari., Siti, D., Purwani, E.Y., Wibowo, P., Jumali. 2008. Nilai Indeks Glikemik Beras Beberapa Varietas Padi. Penelitian Pertanian Tanaman Pangan. 2(3)

Marsono, Y., Wiyono, P., Noor, Z. 2002. Indeks glikemik kacang-kacangan. Jurnal Teknologi dan Industri Pangan 13(3): 13-20.

Marsono, Y. 1998. Perubahan kadar resistant starch (RS) dan komposisi kimia beberapa bahan pangan kaya karbohidrat dalam proses pengolahan. Prosiding Seminar Nasional PATPI. Yogyakarta.

Mcgonigal, A., Jane, K. 2008. Low Glycemic Index Diets. The Journal for Nurse Practitioners - JNP. American College of Nurse Practitioners. 689-696

Oba., Shino., Chisato, N., Kozue, N., Kaori, F., Toshiaki, K., Naoyoshi, T., Hiroyuki, S. 2010. Dietary glycemic index, glycemic load, and intake of carbohydrate and rice in relation to risk of mortality from stroke and its subtypes in Japanese men and women. Metabolism Clinical and Experimental 59: 1574-1582. 
Pateda,., Vivekenanda., Lora., Sri, N., Nanis, SM., Aman, P., Bambang, T. 2009. Pengaruh Konsumsi Beras Indeks Glikemik Rendah Terhadap Pengendalian Metabolik Diabetes Melitus Tipe-1. Sari Pediatri, 10(5): Februari 2009 indeks.

Rimbawan dan Albiner, S. 2004. Indeks Glikemik Pangan. Bogor: Penebar Swadaya.

Sinaga, E. dan Wirawanni, Y. 2012. Pengaruh pemberian susu kedelai terhadap kadar glukosa darah puasa pada wanita prediabetes. J. Nutr. Coll. 1(1): 563-579.

USDA National Nutrient Database for Windows Standard Refrence Release SR 24. 2011. Nutrient Data Laboratory. Agriculture Research Service.

Widowati, S. 2007. Pemanfaatan Ekstrak Teh Hijau (Camellia sinensis) Dalam Pengembangan Beras Fungsional untuk Penderita Diabetes Melitus. [Disertasi]: Sekolah Pascasarjana, Institut Pertanian Bogor.

Widowati, S., Astawan, M., Muchtadi, D.,Wesdiyati, T. 2007. Pemanfaatan Ekstrak Teh Hijau (Camellia sinensis O.Kuntze) dalam Pengembangan Beras Pratanak Fungsional. Prosiding Seminar Nasional PATPI 2007: 975-987

Widowati, S. 2008. Pengolahan Beras Pratanak. Informasi Ringkas Bank Pengetahuan Padi Indonesia. http://pascapanen.litbang.deptan.go.id . Diakses tanggal 16 Februari 2015 Pukul 10.00 .

Widowati, S. 2009. Penurunan Indeks Glikemiks berbagai Varietas Beras melalui Proses Pratanak. Jurnal Pasca panen. 6 (1): 1-9 